\title{
Sexual Violence in Indian Public Sphere: Counter-public Creation and Deferral
}

Sakshi Singh ${ }^{+*}$ and Dr Anurag Kumar ${ }^{\dagger}$

\section{Abstract}

The paper hypothesises that public and counter-public spheres are rhetorically constructed and argues that the nature of rhetoric in both the spheres is dialectically construed by various agencies which on the one hand ensure the execution of public sphere rhetoric, and on the other hand, defer counter-public discourse to be implemented in practice, especially in case of sexual violence against women in India. The paper contextualises the same argument using various newspaper articles which are reflective of the ineffectiveness of the rhetorical counter-public and its consequent deferral.

Keywords: Public Sphere, Counter-public, Sexual violence against women, Dialectic, Deferral, India

\footnotetext{
${ }^{+}$School of Languages and Literature,Shri Mata Vaishno Devi University, India *Corresponding Author, Email: sakshi3344@gmail.com

(C)2019 Singh and Kumar. This is an Open Access article distributed under the terms of the Creative Commons Attribution License (http://creativecommons.org/licenses/by/2.0), which permits unrestricted use, distribution, and reproduction in any medium, provided the original work is properly cited.
} 


\section{Introduction}

The 2017 report published by the UN Women on the status of violence against women states that "...35 per cent of women worldwide have experienced either physical and/or sexual intimate partner violence or sexual violence by a non-partner at some point in their lives. However...studies show that up to 70 per cent of women have experienced physical or sexual violence from an intimate partner in their lifetime" ("Facts and Figures", 2017, para.1). Such statistics are indeed an eye opener revealing the severity of rape that has become a widespread, pervasive phenomenon perpetuating in every corner of the world. This grave and sensitive issue are further escalating incessantly in India where rape cases which are reported, have "climbed [from] 60\% to around 40,000 in 2016 ...The conviction rate of people arrested for rape remains stuck at around 25\%." ("Speedy Justice", 2018, para. 5). Despite, significant reforms in the laws ${ }^{1}$ or the protests taking place all around the country, rapes against women continue to persist.

Further, the relationship between sexual violence and bourgeoisie Indian public sphere is a matter of investigation because public sphere in India succeeds in diffusing patriarchal mindset in the society through rhetorical discourses which in turn get translated into actual practice (Pleasance, 2015; "Woman raped", 2017; Bhalla, 2013; "Policewoman constable", 2017). However, the alternate discourses created against this patriarchal public sphere, either in print or through activism, fail to create an informed and required impact to curb the insensitive crime. Therefore, there lies a disputable relationship between the Indian bourgeoisie public sphere and the reactionary discourses in the cases of sexual violence against women as both are rhetorically constructed. But it is only the misogynist ideology of the public sphere that gets effectively disseminated in the society, unlike the recurrent resisting efforts conceived in opposition to them.

Habermas's concept of public sphere popularly called as the bourgeoisie public sphere, discusses the idea of "public sphere constituted by private people" (Habermas, 1989, p.30) with an aim of a proper "regulation of civil society" (Habermas, 1989,p.52) and how this practice benefits society as a whole. The public sphere represents a group of "private persons" (Habermas, 1989, p.28) gathered to discuss issues of public concern or "common interest" (Habermas, 1989, p.56), which worked parallel to "absolute sovereignty" (Habermas, 1989, p.54) of the state by acting as a mediator between the state and the society in order to create a free flow of opinions and demands to be exchanged between the state and the common people, thus, establishing a strong public opinion for the benefit of the citizens. The formation of the public sphere seems indispensable considering the existence of strong rhetorical practices which provide a powerful medium to discuss and debate different viewpoints that become instrumental in the formation of true democracy in the society. However, Habermas's public sphere is heavily critiqued by Nancy Fraser (1990) foregrounding various exclusionary practices which are intricately constitutive of the bourgeoisie public sphere, referring to it as a biased space which refrains equal and fair participation in the rhetoric praxis of public sphere. The exclusion based upon "race, gender, and class identities" (Loehwing \& Motter, 2009, p.223) from bourgeois public sphere results in the formation of counter-publics, the "parallel discursive arenas where members of subordinated social groups invent and circulate counter-discourses, which in turn permit them to formulate oppositional interpretations of their identities, interests, and needs" (Loehwing \& Motter, 2009, p.223). Taking Fraser's point of contention into consideration, Habermas's concept appears to be gender biased due to an

\footnotetext{
${ }^{1}$ The Vishakha Judgement was passed to protect women from being physically or mentally harassed at workplaces. The judgement "laid down the requirements for employers dealing with complaints of sexual assault and stipulated the formation of committees to dispose of complaints from victims of harassment" ("Sexual Harassment", 2013, para. 3).
} 
apparent exclusion of women from the public sphere. This is precisely the reason that Fraser calls Habermas's public sphere "bourgeois, masculinist,... public sphere" (Fraser, 1990, p.62) as it functions exclusively on the principles of patriarchal bourgeoisie ideology. A democratic society consists of varying groups who are equally responsible for the growth of society, and their discursive practices are equally important in strengthening democracy. Therefore, Fraser proposes the presence of "multiplicity of the public" rather than having a single dominant public sphere, which helps to inculcate the idea of equality in the existing public sphere. Though, Fraser, in the process of critiquing Habermas's public sphere does not completely reject the notion of the public sphere, rather, she apprehends the "political and theoretical importance of [Habermas's] idea" (Fraser, 1990, p. 56) since according to her, the public sphere, "provides a way of circumventing some confusions that have plagued progressive social movements and the political theories associated with them" (Fraser, 1990, p. 56). Habermas's public sphere indeed establishes a parallel discursive arena along with the state in order to provide a platform for the public, allowing them to have an extensive discussion and debate to create a comprehensive discourse validating the prominent prevalence of rhetorical practices in the bourgeoisie public realm.

In a democracy, rhetoric acts as a medium of communication between the state and the common people which further strengthens democracy in the society. Rhetoric is the most fundamental tool for the people that can question the decisions and functioning of the state which further helps in establishing a society. According to Loehwing and Motter (2009), "Habermas's characterization of the public sphere-and the rhetorical work of citizens that creates it-posits the necessity of an always negotiated and renegotiated ecology between liberalism's injunction to protect individual rights and needs and democracy's promise of self-rule and popular sovereignty" (p.236) which makes the public sphere highly rhetorical in nature. Charles and Rohwer (2015) suggest that reason serves as a significant element in the public sphere and the "reason through speech served as the principal medium of communication" (p.2). In fact, "participants in the public sphere were not to be distinguished on the basis of their station in life but in the strength of their ideas" (p.4) indicating the necessary role of rhetoric in the bourgeoisie public sphere. The same thought is also elucidated by Fraser (1990) who remarked that, "[the public sphere] designates a theatre in modern societies in which political participation is enacted through the medium of talk...space in which citizens deliberate about their common affairs...institutionalized arena of discursive interaction...site for production and circulation of discourses" (as cited in Charles and Rohwer, 2015, p.2). Counter-public, too, centres its approach in allowing a wider participation of people in a rhetorical space as it "emphasizes a sense of democracy that positions direct and expanded participation in decision-making mechanisms as its core focus" (Loehwing \& Motter, 2009, p.236) which in turn, helps the democracy thrive and flourish for the betterment of the society. Therefore, we realise that all the public and counter-public discourses are rhetorically constructed, establishing rhetoric as an essential component in the "social praxis that constitutes the communities, ideologies and citizenship" (Loehwing \& Motter, 2009, p.221) and effectively acts as a medium for the individual needs and demands to be communicated and realised in practice. However, how successfully the rhetoric accomplishes its function of actually realising the demands of the public, is quite uncertain.

Therefore, the paper attempts to analyse how the dialectical nature of rhetoric affects the efficacy of the mainstream public discourse as well as the simultaneously subsisting endeavours countering the dominant ideology especially in case of sexual violence against women. On the one hand, the rhetorical practices in case of the bourgeois public sphere get translated into social practice, on the other hand, it fails to produce the desired outcome when it comes to the oppositional discourses of excluded groups, especially women, by not being 
able to transform itself into reality. Therefore, the constant efforts of creating a counterhegemonic discourse in opposition to the bourgeoisie public sphere are perpetually interrupted which in turn, procrastinates the social justice for the victim, is reflective in the already prevalent agencies of the society ("Remember Kathua", 2018; "Gender justice", 2018; Biswas, 2013; Wangchuk, 2018; Gunjan, 2018). The next section outlines the methodological issues underpinning this study.

\section{Research Methodology}

The present study employs the concept of a public sphere given by Jürgen Habermas as the foundational framework of the research to assess and explore the Indian public sphere. Habermas's public sphere popularly called the bourgeoisie public sphere endeavours to create free discursive space to discuss the issues of public concern. The study incorporates the works of Nancy Fraser, Loehwing and Motter who have critiqued Habermas's public sphere foregrounding the practices of gender exclusion which are intricately constitutive of the bourgeoisie public sphere, referring to it as a biased space which refrains equal and fair participation in the rhetoric praxis of the public sphere. Critics of the Indian public sphere like Neera Chandhoke (2007), Gurpreet Mahajan(1999), Richa Tiwari(2006), etc. have also been employed in the paper for further analysis.

The study attempts to focus on the existing public discourse (using newspaper articles, interviews, journal articles and others) in India to analyse how the Indian public sphere operates along the lines of patriarchal bourgeoisie public sphere excluding the alarming issue of sexual violence against women from its discursive arena. The research also incorporates the conceptualisation of counter-public created against the exclusionary practices of patriarchal bourgeoisie public sphere to raise awareness about the denial of justice to the victims of sexual violence.

The paper is divided into various sections contending that there exist successive agencies of public sphere like the public, family, the state agencies (police, judiciary), media and alike which further become significant hurdles in the way of social justice being served to the victim in the bourgeois public domain thus, deferring the counter-public and providing impunity to the culprits.

\section{Indifferent Public and Sexual Violence against Women}

The notion of the public sphere as given by Habermas makes us acquainted with the discursive space which harbours in itself "rational discussion of public matters" (Fraser, 1990, p.59) and "the discussion was to be open and accessible to all" (Fraser, 1990, p.59). However, the public sphere prevalent in Europe differs significantly from that of India considering there lies a certain uniformity in the public sphere of Europe where "popular identification with local community became transmuted into identification with a larger entity" (Ali, 2001, p.2420). However, India sustains different cultures and communities, thereby, suggesting "the inability of the [single] public sphere to reflect a plurality of cultures [which has] resulted in its inaccessibility for members of minority groups and hence their exclusion from it" (Ali, 2001, p.1). This dissimilarity in public spheres is further underlined by Tiwari (2006) who maintains that due to "lack of...creating an unbiased and rational public sphere...the partisan and sectarian attitude of the public sphere has ...become deeply ingrained in the mindset of the public sphere in India. She attributes the peculiar functioning of [the] Indian public sphere to "the continuous failure of efforts to bring about a significant paradigm shift in the social structure" (Tiwari, 2006, p.647).

As a consequence, there exist mutual sustenance of contesting public spheres and the one acquiring the political power and dominance becomes synonymous with the exclusive public sphere, for instance, Ali (2001) mentions the emergent surge of Hindu nationalism which has begun to form the conventional public sphere. He avers, "the public sphere [is] being defined and dominated by majoritarian values and norms, which have been considered neutral. This 
particular tendency has been further accentuated and exacerbated by the recent rise in the Indian polity... of Hindutva or Hindu nationalism" (Ali, 2001, p.2419). Therefore, the governing public sphere attains a position where its beliefs and ideologies diffuse in mainstream society to be followed by the public. However, it cannot be ignored that the entire conception of the public sphere is rhetorically constituted and the actual implementation of the public sphere depends on the dialectics of the rhetoric.

The public sphere is constitutive of the state and the civil society and over the years, it has remained debatable whether civil society stands "in opposition to the state" (Mahajan, 1999, p.3471) or as a body that is "associated with a set of institutions that mediate between the individual and the state" (Mahajan, p.3471). While the nature of the relationship between the two has remained contested, Mahajan (1999) establishes that "in a democracy, the state and civil society act together...to promote citizenship rights" (p.3471). Nevertheless, how successful this union remains is questionable because "citizenship rights can be protected and promoted only when opportunities and privileges are more or less equally distributed" (Mahajan, 1999, p.3471). However, the Indian public sphere is not uniform in its structure because the "secularity and equality are being eroded by this nasty play of sectarian and caste oriented outlook" (Tiwari, 2006, p.647). There are "communities that have been forcibly excluded from social and political life" and do not have "access to assets that are valued in the society" (Mahajan, 1999, p.3471). As Chandhoke (2007) mentions, "it is the urban middle-class agenda that is best secured by the invocation of civil society.The agenda of oppressed...or tribals...remain unrepresented either in theory or in the practice of civil society" (p. 613). Additionally, the "civil society cannot be conceptualised in abstraction from the state, because it is the state that establishes the boundaries of civil society" (Chandhoke, 2012, p.40), revealing that "civil society too is a contested site" (Chandhoke, 2007, p.613).
Consequently, the state allows selective rhetorical discourse, which it conceives within its premises, to be transferred to the civil society. As a result, this rhetorical discourse which is highly misogynistic and exclusive in its creation is manifested by the civil society and practised by the public. The state, civil society and the public operate in transcending the patriarchal norms and beliefs from its rhetorical space into reality, thus, confining the society into a rigid perimeter and "groups, who transgress [this perimeter],...are... excluded from space which happens to be dark, damp,...here, we find neither rights nor justice" (Chandhoke, 2012, p.40).

The public, being the major constituent of bourgeoisie public sphere overtly exemplifies the manifestation of dialectic nature of the rhetoric, which on the one hand promotes the patriarchal norms and customs to be realised in social practice, on the other hand, restrains the transcendence of the defying ideologies created by women into reality, thus, suspending their effectuality in the social praxis. This is elucidated from the news which was reported from Uttar Pradesh in 2015 that a young girl was murdered by her own father, brother and various other relatives and villagers by pelting stones at her because she fell in love with a boy from the neighbouring village. In fact, the "officers [Police] believe the girl was beaten with bricks and stones before being strangled to death, and that more injuries were inflicted" (Pleasance, 2015). This group is the representative of the public which is operative in disseminating the patriarchal ideology that a woman does not possess the right to choose the life she desires and ought to follow what is imposed on them and if she questions the norms of the patriarchy, she is brutally punished. In another incident in Vishakhapatnam reported the rape of a woman on the road in broad daylight and "people passing by did not bother to stop [the man] even as the woman was too weak to even scream" ("Women raped", 2017, para.6). Thus, the patriarchal beliefs get transcended unquestionably from its rhetorical public sphere to be effectively realised in actuality. In another incident which recently took place in Kathua 
region of Jammu reported that an eight-year-old girl, Asifa was, "abducted, drugged, confined in a temple, repeatedly beaten and raped and then murdered and thrown out" ("Remember Kathua", 2018, p.7). In fact, one of the accused policemen pretended to help by "join[ing] the search party with her parents...all the time aware of where she was and what was being done to her" ("Remember Kathua", 2018, p.7). It is also disgusting to witness that the educated and reputable people of the state came out in support of the accused defying their arrest "marching with the national flag and demanding justice for the accused" [the lawyers, too], "physically tried to prevent the police from filing the charge sheet" ("Remember Kathua", 2018, p.7). It becomes perceptible that the educated citizens of the public sphere, too become indifferent towards the cases of violence against women, dragging such an intense and grievous episode into politics which "many see it as a possible means of diluting the case against the accused" (Zargar, 2018). In the wake of such a scenario, sexual violence against women does not get restricted to certain spaces but also reaches the most revered places in the public sphere. Recently, a nun from Kerala has come out accusing the Bishop of a Catholic church in Kerala, "of sexually abusing her several times over the course of two years" ("Gender Justice", 2018, p.7). In an attempt to demand justice, the nun "petitioned the head of the Syro-Malabar Catholic Church, the Apostolic Nuncio of India, and church officials in Rome, including the Vatican state secretary and the Pope" (p.7). Regardless of the nun's plea, the decision by the church authorities was taken in the favour of the accused. However, when the Supreme Court rejected the bail plea of the Bishop "the church, in an attempt to establish its own patriarchal morality...treated gender justice as an "inhouse" question to be settled within the community...Community logic led the church to issue a moral caution that the nun's attempt to appeal for justice in public would tarnish the image of the community" (p.7). It is apparent that there is indeed a struggle to form a strong and authentic arena which addresses to the needs of rape victims against the ruling authorities of the Bishop and church but somehow, such efforts are being dampened. Later, when the accused Bishop named Franco Mulakkal, was released on bail, he "received a grand welcome in Jalandhar... Mulakkal smiled as followers showered rose petals on him" ("Kerala Nun Rape", 2018, para 1-2). As stated above, similar events had unfolded too in the 2018 Kathua rape case when people took to the streets "marching in support of the accused, chanting religious slogans, waving the tricolour and calling for a bandh.... [the lawyers, too, declared to] shut down a city in India so that criminals are not arrested" (Sharma, 2018, para 9). This is how the public, in the Indian public sphere, treats the culprits accused of rape, celebrating their valorisation and exhibiting open and unquestionable support to them.

The recent \#metoo movement in India has also caused a lot of stir "after [Bollywood] actress Tanushree Dutta accused Nana Patekar [actor] of inappropriate behaviour on the sets of a film they were shooting in 2008" ("\#MeToo", 2018, para.1). Consequently, many women have come out of the closet to share their gruesome experiences of sexual assault at workplaces by famous and popular celebrities coming from different fields of entertainment, journalism, politics etc. For instance, the famous Bollywood actor Aloknath, who is well known for his portrayal of a traditional father on screen, is accused of assault and rape by TV writer, director and producer Vinita Nanda. She revealed on her Facebook account that "I was invited to a party at this man's house...At around 2 am...I started to walk home...he asked me to sit [in his car] and offered to drop me home...। can remember more liquor being poured in my mouth and I remember being violated endlessly" (Krishnamurthy, 2018, para.3-5). Similarly, Bollywood director Sajid Khan has also been accused by three women who "have spoken about the harassment they faced at the hands of Sajid. These include actor Rachel White, assistant director Saloni Chopra and a journalist" ("Sajid Khan accused", 2018). The list of accused continues from former Union minister M J Akbar to celebrities like Vikas Bahl (director), Rahul Johri (BCCl CEO), Jatin Das (painter) and many 
more. Despite so many women coming out in public and shaming the culprits, the public constantly shifts its focus on "why most victims chose to remain silent" (Bhattacharyya, 2018, p.7) for so many years. Bhattacharyya (2018) has responded to such questions saying that "it is not easy for a woman to speak against the sexual misconduct of the perpetrator, for reasons such as sheer embarrassment of being labelled as 'characterless' or 'bad woman, accusations of lying, fear of ruining their career, the threat from the perpetrator(s), etc" (p.7). Nevertheless, the women "through shared experiences,...are creating another knowledge: that of lived reality" ("How to Believe", 2018, p.8), in an endeavour to resist the hegemony of the misogynist powerful culprits. However, the effectiveness of such struggles still remains a question because "woman's word is always subjected to tests of patriarchal knowledge" ("How to Believe", 2018, p.8). Therefore, the public continues to conform to the neglected attitude of the bourgeoisie public sphere towards violence against women and in turn partake in defending the assailants, thus, restraining the justice to get well served. Robert Asen and Daniel Brouwer (2001) suggest that the "rhetorical studies...identify [the] need for counter-public as a critical term that serves as a corrective to Habermas's public sphere" (as cited in Loehwing \& Motter, 2009, p.228). Despite a bold and undaunted effort to authenticate the rhetorical viewpoints against sexual violence against women, it does not come across as a successful manoeuvre considering the crowd does not seem to take any action, standing at the sight of the assault as meek spectators, thus, becoming instrumental in not permitting the execution of the defiant rhetoric in reality.

One of the primary examples of the significant endeavours in the modern Indian public sphere goes back to former times where sexual violence against women has been observed as a matter of consideration. Nivedita Majumdar emphasises on how Gayatri Spivak's essay Can the Subaltern Speak (1988) focuses on "the acknowledgement of subaltern - especially women's - agency and an acknowledgement of its suppression" (Majumdar, 2017, para. 27). According to
Majumdar, Spivak attempts to create a parallel space for women "to recover and acknowledge instances of women's resistance that either is ignored by establishment discourses or are suppressed in the exercise of power" (Majumdar, 2017, para.27). Discussing the case of Bhuvaneswari Bhaduri, who committed suicide in Calcutta in 1926, Majumdar exemplifies her defiance against the already established patriarchal realm. Bhuneswari deliberately, committed suicide during her menstruating period to justify her maidenhood "because, in the patriarchal culture of Bengal, when teenage girls committed suicide, it was typically assumed that they had done so to cover up a sexual tryst that had been or was about to be discovered" (Majumdar, 2017, para.30). Her suicide exhibited her counteraction and hostility against the patriarchal order, thus, interrogating stereotypes and perceptional bias against women in the public sphere. Even in the 1960s and 1970s, there have been social movements started by various independent women's groups against the patriarchal dominant domain (Desai, 1997; Sethi and Kothari, 1983). Such protests and demonstrations led to the formation of Report of the National Committee on the Status of Women "set up by the Indian government in preparation for the 1975 International Women's year" which further became instrumental in creating various "informal groups...[which] portrayed the deteriorating conditions of women...unemployment...literacy gap between men and women...declining sex ratio" (Desai, 1997, p.112). Besides the groups and organisations led by women, there were various magazines and journals which were also written for the cause of upliftment and validation of women. One such journal was Manushi which was involved "in the rural and urban struggles of daily wage earners, such as agricultural, industrial, and construction workers; street vendors; and local service providers, as well as those faced by women professionals, students, and middle-class homemakers" (Batra, 2016, p.847). It became a significant counter response "to popular women's magazines such as Femina and Women's Era, which enjoyed a national circulation based on a middle-class female 
readership interested in fashion, food, and romantic fiction, as well as marital, romantic, and incidentally some career advice" (Batra, 2016, p. 847-848). As evident as it seems, there have been umpteen attempts of forming counter-publics in support of women but such endeavours, too, had their own challenges and hardships. The distinct autonomous women's groups governed by various female activists could not get any assistance from the male counterparts "who worked on a more important class or caste issues...despite the emphasis on multiple sources of oppression, women's oppression was seen secondary to class oppression" (Desai, 1997, p. 111-112). While there were legal reforms made by the state to prevent rape, dowry, ${ }^{2}$ sati, $^{3}$ etc., there was no implementation of any of these changes which "meant a minimal impact on women's lives" (Desai, 1997, p.114).

Additionally, the religious fundamentalists too were against such activism by women "accus[ing]...[them]..of being westernised upper-class women who do not speak for the masses or real Indian women" (Desai, 1997. p.117), calling them "pseudo-secular feminists" (Desai, 1997, p.118). It is evident that there were indeed many attempts which strived for seeking safety and protected realm for women against the dominant patriarchal regime, but the bourgeoisie public sphere continued to restrict it to the rhetorical space through its institutions and agencies.

Even today, the exclusion of women and sexual violence against them, continue to encounter obstacles which refrain their transcendence from rhetorical space into actuality, either leading to their ineffectuality or deferral. The failure of proper execution of rhetorical discourse concerning sexual violence in practice was also witnessed in 2012, after the most disturbing and depressing case of Nirbhaya

\footnotetext{
2 Dowry "or Dahej is the payment in cash or/and kind by the bride's family to the bridegroom's family along with the giving away of the bride (called Kanyadaan) in Indian marriage" (Reshma \&Ramegowda, 2013, p.37).

${ }^{3}$ Sati "(also called suttee) is the practice among some Hindu communities by which a recently widowed woman
}

whose rape brought a wave of revolutionary protests demanding justice in the country. In December 2012, Nirbhaya or Jyoti Singh Pandey, a 23-year-old, was returning home after watching a movie with her friend "when they were offered a ride in a private bus" (Presse, 2018, para.3; Bhattacharyya, 2015; 2016).While on the bus, "[s]ix men, including a juvenile, beat Nirbhaya's friend unconscious before raping and torturing her with an iron bar as the bus drove loops through the city" (Presse, 2018, para.3). After struggling for thirteen days in the hospital, Nirbhaya lost her life due to excessive internal injuries. The incident led to a revolutionary protest where people "took to the streets of Delhi demanding swifter justice for victims and tougher laws to punish perpetrators" (Presse, 2018, para.4). The huge demonstration was seen raising slogans, holding placards. People could see their reflection in the innocent young girl who lost her life to the savagery of men. Such strong and powerful protests and marches played a gigantic role in raising people's consciousness. Majority of the youth along with older adults in Delhi and different parts of the country came out on roads lashing against the government and the existing laws which failed miserably to ensure the safety of women. Yasminah Beebeejaun sees it as a failure of urban planning highlighting "how claims to urban space and the exercise of rights are inherently gendered" (Beebeejaun, 2016, p.323). The severity of this incident was also stressed by the media which remained a major tool in escalating the rage and anger against the sexual violence throughout the country. It broadcasted the ongoing struggle and objection raised by the public ensuring that there remain a worldwide sensibility and vigilance at the same time. The constant debates and discussions organised by various prominent news channels emphasised the ineffectiveness and ignorance of the state forces to bring justice to the sufferers.

either voluntarily or by use of force or coercion commits suicide as a result of her husband's death. The best-known form of sati is when a woman burns to death on her husband's funeral pyre. However other forms of sati exist, including being buried alive with the husband's corpse and drowning" (Heaphy, 2017, para. 2) 
The repeated telecasts of Nirbhaya's rape invited various campaigns and demonstrations from various social activists demanding the right to safety for women. The social media like facebook, twitter, too, was filled with furious reactions mocking the government and hurling ridicules at the violators. The massive movement appeared to be the commencement of a greater counter-public which would create the muchneeded awareness concerning sexual violence against women, in the social, discursive realm. As a result, a committee headed by late Justice J.S. Verma was set up to suggest new recommendations in the criminal laws for the safety of women, thus leading to the formation and passing of the Criminal Law Act, 2013 (Bhattacharyya, 2013; 2015). The criminal law Act "expanded the definition of rape to include oral sex as well as the insertion of an object or any other body part into woman's vagina, urethra, or anus" (Sachdev, 2017, para.3; see for details, Bhattacharyya, 2013). Further, the law against the punishment also became more strict as "the court's discretion to give rapist's a sentence less than... seven years was abolished...[along with] punishment for repeat offenders...including the possibility of a death sentence"(Sachdev, 2017, para.3). It must be taken into account that the inception of the amendments above did not just begin with the frightful episode of Nirbhaya's rape. In fact, the outrage and uproar against the malignity of rape has been witnessed through women's groups like Gulabi Gang which was formed in 2002 to fight against the atrocities committed against women in Badausa, Uttar Pradesh, "a region notorious for its record of rape crimes, dowry deaths and domestic violence" (Bordia, 2017, para 2). The gang was founded by Sampat Pal who talked about forming the famous women's gang asserting that, "it's the only way people in this violent region will understand that women can retaliate" (Bordia 2017, para 2), thus exemplifying the gang's spirit of challenging the misogynistic activities of the public sphere.

\footnotetext{
${ }^{4}$ Dalit, also known as untouchables are the people from the lowest strata of the hierarchal Hindu Caste System. According to "Rig Veda hymn Parusukta, the four varna or orders formed the limbs of primeval man...The Brahmins
}

Similarly, there has been the famous Mathura rape case, in which an Adivasi (tribal) girl named Mathura was brutally raped by policemen who were later acquitted by the Supreme Court "on the grounds [that since she had] eloped with her boyfriend" (Dutta and Sircar, 2013, p.296), it automatically made her a woman of loose morals. Also, the fact that there were no injuries on the bodies of the officers, further, substantiated "her consent to sex" (Dutta and Sircar, 2013, p.296). The ridiculous and demeaning judgement by the court led four law professors to write an open letter to the Chief Justice "accusing the judges of sacrificing human rights of women under the law and the constitution" (Dutta and Sircar, 2013, p.296). The open letter became groundbreaking in sprouting nation-wide protests and campaigns along with self-governed groups such as "Forum against Rape in Bombay, Saheli in New Delhi, Vimochana in Banglore and Chingari in Ahmedabad" (Desai, 1997, p.113). These groups also campaigned actively against "dowry deaths, wife-battering, sex-selective abortions, sati..." (Desai, 1997, p.113). The Mathura case was also revolutionary in reforming the rape laws in the country. Furthermore, the gang rape of Bhanwari Devi (a Dalit) 4 by upper caste Gurjar men in 1992 also provoked huge rebellion in support of Dalit women being targeted and violated sexually by the upper caste men which eventually "prompted the Supreme Court to pass historic guidelines on sexual harassment in the workplace in 1997, known as the Vishakha Judgement" (Dutta and Sircar, 2013, p.296-297). Later, Sexual Harassment of Women at Workplace (Prevention, Prohibition and Redressal) Act 2013, which was formed "to ensure a safe working environment for women" (Bagaria, 2013, para. 1), was "formed on the basis of the guidelines laid down by the Supreme Court in its landmark judgement, Vishakha $v$. [the] State of Rajasthan...but is much wider in scope, bringing within its ambit the domestic worker as well" (Bagaria, 2013, para.1).

emerged from mouth, the Kshatriyas from his arms, Vaishyas from his thighs and Shudras from the feet. The untouchable castes find no mention in the hymn. (Srinivas, 1985, p.150-51). 
However, it seems that the effectiveness of the movements created by various women groups, or cases like that of Mathura, Bhanwari or Nirbhaya, somehow got curbed because sexual violence against women continues to rise as suggested by the report released by National Crime Records Bureau showcasing that the cases of sexual violence have increased from " 36,735 in 2014" (NCRB, 2014) to "38,947 in 2016" (NCRB, 2016). The other recent incident which came into the public domain is of women being sexually harassed during the celebrations of Holi festival in Delhi. "Holi is meant to be a Hindu festival celebrating the start of spring, but in Delhiite's being used as an excuse for men to harass and sexually assault women in public places" (Heanue, 2018). Normally, people throw balloons filled with water and coloured powders on each other as part of the festival "but Delhi women have reported being struck with balloons filled with semen and urine" (Heanue, 2018). Women took to social media to show their disgust and "few even objected that the balloons are often flung from men riding motorbikes and aimed at their breasts, hips or genitals" (Heanue, 2018). However, such cases of assault are not restricted to Holi or any other festivity but can take place anywhere in the public sphere. Such instances, where women are freely violated and exploited, give the testimony of the successive failures of counter-discourse into practice which is, otherwise, powerful and influential in making its mark in the social, discursive dominion. Table 1 summarises the horrifying incidents of sexual violence against women which continue to perpetuate in the society and how they are seen and defended by the indifferent crowd of the bourgeoisie public sphere. Hence, the data of sexual violence against women as given by the National Crime Records Bureau (NCRB), police and newspapers indicate that the discursive rhetoric to end violence against women is not being translated into practice.

\begin{tabular}{|c|c|}
\hline Incidents & A Reaction of the Public \\
\hline $\begin{array}{l}\text { Young Girl in Uttar Pradesh fell in love with a } \\
\text { boy from the neighbouring village }\end{array}$ & $\begin{array}{l}\text { Stoned to death by her own father, brother and } \\
\text { relatives (Pleasance, 2015, para. 1) }\end{array}$ \\
\hline $\begin{array}{l}\text { A girl of } 8 \text {, brutally gang-raped and murdered in } \\
\text { Kathua for a week }\end{array}$ & $\begin{array}{l}\text { The culprits supported by lawyers and } \\
\text { politicians dragging the matter into religious } \\
\text { politics (Remember Kathua", 2018, p.7) }\end{array}$ \\
\hline $\begin{array}{l}\text { A woman raped on the roadside in } \\
\text { Vishakhapatnam }\end{array}$ & $\begin{array}{l}\text { People recorded the whole act, and some } \\
\text { walked past it ("Woman raped", 2017, para.1) }\end{array}$ \\
\hline
\end{tabular}

\section{Media and Sexual Violence against Women}

Media, in many cases, plays a subservient role in the patriarchal bourgeoisie public realm by the way of projecting a woman on screen. It often portrays women in the most alluring and enticing manner which incites the audience to evaluate them purely on the basis of their physicality, from the facial beauty to the bodily figure, reducing them to a mere object of fascination and conforming to the principle of confined outlook towards women as set by the bourgeoisie public sphere. According to Geetha (2013), "in filming the item number, the camera does not get away from particular parts of the women's body, navel, breasts or buttocks..." (p.17). Media being a powerful medium always possess an influential control over the audience. The movies, for example, showcase the women in sleazy item numbers, objectifying them making them look like an eye candy which influences an atrocious and nasty reaction from the patriarchy, thus, actuating the patriarchal norms into practice. For instance, the song $T u$ Cheez badi hai mast mast' from the film Mohra shows the hero calling his heroine Cheez, that is, an object, thus, substantiating that the public sphere majorly accepts the objectified image of women because "in this public sphere, the media that constitute the material support for the circulation of views are privately owned and operated for profit" (Fraser, 1990, p.64). The media has such a deep impact on the people that it becomes instrumental in transferring the 
prevailing patriarchal rhetorical implementing them in the social realm.

On the contrary, it is also apparent that the media does take initiatives to reach to the audiences with the aim of raising awareness and making people educated about the seriousness of sexual violence against women. There have been television shows or debates which are aired exclusively to create an informed environment about the severity of the issue. For instance, Satyamev Jayate, a television show hosted by Mr Amir Khan, the Bollywood actor and anchor has been significant in raising extremely relevant issues concerning women like dowry system, female foeticide, and alike. One such episode has been on sexual violence against women which exhibited the excruciating and disturbing plights of women who are forcefully victimised at the hands of the assailants. The show has received rave views, and nationwide acceptance for its endeavour to raise consciousness among people for it created a significant impact on its audience, thus, contributing towards a progressive change. However, such initiatives still remain unsuccessful for women to be realised in reality which is elucidated from recent news in Mumbai where the popular choreographer Saroj Khan's comments on the infamous casting couch prevalent in the Bollywood film industry caused a lot of frenzy in the media. She remarked, "Yeh to chala aa raha hai adam ke zamaane se, Abhi se thodi? Har ladki ke upar koi na koi hath saaf krne ki koshish karta ha...Tum film industry ke peeche kyu pade ho? Wo roti to deti hai. Rape karke chhor to nahi deti" (This has been happening for generations. It's nothing new. Someone or the other tries to paw every girl. Why are you after the film industry? At least it gives you food. Doesn't rape and then abandon you) (Das, 2018). Khan's comments explicitly suggest that an assault on a woman whether in the form of rape or casting couch is happening everywhere in the country which makes it a highly pervasive phenomenon. Moreover, she justifies the presence of casting couch in the film industry with the emphasis on employment that a woman might secure for herself in return which makes it an absolute vague argument.
Being a renowned personality and a woman herself, she possesses a power of agency which can be utilised to educate people about the heinous offence. However, her remarks appear to be less sensitive and more unconcerned. Such incidents become reflective of the dialectic rhetoric which "enables...counterpublics partially to offset, although not wholly to eradicate, the unjust participatory privileges enjoyed by...dominant social groups" (Fraser, 1990, p.68).

\section{State Agencies and Sexual Violence against Women}

The dialectic nature of rhetoric is prominently observed in the existing state agencies like police, judiciary and alike, which ideally should help the victim with their grievances by working towards eradicating violence against women. Unfortunately, these functionaries are entirely driven by the function of the dominant bourgeois public sphere, thereby, suspending the validity of an equal and strong parallel discursive space, as mere rhetoric.

\section{Police and Sexual Violence against Women}

The police, an essential and respectable bureau of the country are bestowed with the responsibility of providing a safe environment for the citizens of the country. While the police succeed in resolving issues like murder, theft, etc. they often stumble through their job when it comes to the matters of women. For example, the police have been in the limelight most of the times for not coming to the rescue or not hearing the victim's plea when it is most required. According to a survey conducted by the Human Rights Watch in various states of India: "[p]olice are frequently unwilling to register their complaints, victims and witnesses receive little protection, and medical professionals still compel degrading "two-finger" tests...In several cases, the police resisted filing the FIR or pressured the victim's family to "settle" or "compromise," particularly if the accused was from a powerful family or community" ("India: Rape Victims", 2017). There are various other instances where police deliberately assist the violators, thus failing to perform their duty. This is evident from an incident where "a 17-year-old 
village girl was drugged and gang-raped by at least two men in a field in the northern Punjab region. The police allegedly failed to take her complaint seriously, and the victim ended up killing herself" (Bhalla, 2013). The cases like murder or a loot gain notable prominence and incidents of sexual abuse or an assault are mainly pushed aside as irrelevant and unimportant by the police as it is apparent in another case which was reported from Odisha in 2017 highlighting the negligent behaviour of the police when a girl after being sexually violated, committed suicide due to the repetitive delays on the part of the police in filing the charge sheet. The news states that "the minor Dalit girl had alleged [that] she was gang-raped by four armed jawans. She had even told newsmen that she was under pressure from the police to withdraw the case and even was offered money by a senior police officer to change her statement" ("Odisha: Alleged", 2018). The news from Pune also shocked the country where the constable and woman police sub-inspector was "allegedly accepting a bribe of Rs 15,000 , to submit a report in favour of a rape accused in [the] court" ("Policewoman, constable", 2017). Such incidents reflect that when it comes to asking for justice, it becomes too complicated for women because they become the prime targets as they decide to go against the powerful hegemonic system of patriarchal bourgeoisie public sphere. Table 2 is an attempt to unfold the incompetency of police towards sexual violence against women. It paints a summary of the inefficiency and indifference of the police towards sexual violence which becomes instrumental in encouraging the frequent occurrences of such crimes in India. Hence, the section deduces that by denying successive action against the violators, the police somehow implement the public sphere discourse of objectification of women's sexuality and therefore, supports violence against women, and fails to implement productive measures to end violence against women.

\begin{tabular}{ll}
\hline Table 2: Illustrates the Incompetency of Police towards Sexual Violence against Women \\
\hline $\begin{array}{l}\text { Incidents } \\
\text { A village girl, drugged and gang-raped in }\end{array}$ & $\begin{array}{l}\text { Reactions of the Police } \\
\text { Punjab }\end{array}$ \\
\hline $\begin{array}{l}\text { A minor Dalit girl raped by army men in Odisha } \\
\text { committed suicide (Bhalla, 2013) }\end{array}$ & $\begin{array}{l}\text { Police continued to delay filing a charge sheet, } \\
\text { and the victim committed suicide ("Odisha: } \\
\text { Alleged", 2018) }\end{array}$ \\
\hline Woman raped in Pune & $\begin{array}{l}\text { The policewoman and a constable took a bribe } \\
\text { of ₹15000 to submit the report in favour of the } \\
\text { accused ("Policewoman, constable", 2017) }\end{array}$ \\
\hline
\end{tabular}

\section{Judiciary and Sexual Violence against Women}

The judiciary also plays an important role in shielding the culprits and exempting them from punishment. There are various instances where there is a delay in the legal proceedings resulting in breaking the confidence of the victim who is already suffering, and also the culprits belonging to the wealthy, influential families try to influence the proceedings of the court which delays justice (Bhattacharyya, 2016). According to National Crime Records Bureau, "the backlog of rape cases pending trial stood at more than 133,000 by the end of 2016, up from about 100,000 in 2012" ("Speedy Justice", 2018, para. $6)$. This is apparent in the case of a girl who was brutally raped in Delhi by the neighbour when she was four and "has been denied justice for nine long years...because the 4-year-old could not answer questions in cross-examination in court" (Biswas, 2013). After nine years, the judiciary acquitted the rapist stating that "there is a possibility of tutoring a child witness. Suspicion, however strong, cannot take the place of proof" (Biswas, 2013) despite the fact that the POCSO Act 2012 states that "the onus of providing proof lies on the accused rather than the victim" (Singh, 2018, p. 08). The other incident from Buldana Tehsil, Maharashtra, showed the molestation of Radhabai Gulabrao who was "stripped and paraded naked by upper 
caste men in her village" (Gunjan, 2018). The case was dragged for nine months after which "the perpetrators are still roaming free" (Gunjan, 2018). As Habermas's bourgeoisie public sphere outright neglects "one side of liberal-democratic law's duality" (Loehwing \& Motter, 2009, p.235), it highlights "the public sphere as the mediating point at which conflicts between challenges to the legitimacy of law intersect with the facts of institutional administration and private needs" (Loehwing \& Motter, 2009, p.235) and that is precisely why the judiciary in India gets stuck in imbibing the principles of the bourgeoisie public sphere and thus, equally participates as an active agent in suspending the rhetorical initiative to end violence against women.

As the police and judiciary are blamed for being biased and practice the misogynist behaviour with the victims of sexual assault/violation, it is also intended to bring forth that over the last few years, some significant amendments and reforms in the laws such as The Criminal Law Amendment Act 2013, Sexual harassment of Women at Workplace (Prevention, Prohibition and Redressal) Act, 2013, Protection of Children from Sexual Offences 2018 regarding sexual violence have been implemented, while the actual impact of these amendments and laws is doubtful. Singh (2018) critically analyses "whether the amended POCSO ordinance, awarding death penalty for raping children up to 12 years, would serve as a deterrent of rape against children" (Singh, 2018, p.8). Quoting from the Criminal Law (Amendment) Act, 2013, passed by the Government of India "and the consequent historic verdict of the honourable Supreme Court of India awarded death penalty to all the four adult perpetrators of Nirbhaya on 5 March 2017" (p.12), Singh sees "little has changed for women on the ground (Khan, 2017) and the death penalty is no deterrent" (p.12). On the similar grounds, Singh argues "that the death penalty incorporated in the POCSO ordinance will prove to be a fruitless exercise in the longrun" (p. 12). Many portals and helplines have also been established in order to provide aid and assistance to the women in the country. However, there happen to be some loopholes in the laws for sexual violence which reflect that the lawmaking process still follows the patriarchal frame of mind existing in the public sphere. For instance, marital rape is not considered a criminal offence by the judiciary (Dwivedi, 2014). The justification is given by Haribhai Chaudhary, Home Affairs minister seems rather absurd who said that "marital rape can't be made a criminal offence in India because of high illiteracy rate, poverty, extreme religious beliefs and the very sanctity of marriage" (Sharma, 2017, para.3). The people openly condemn the decision of the judiciary against marital rape considering the wife, if sexually violated is forcefully refrained from justice, in order to preserve the sanctity of marriage. On the contrary, the Supreme Court of India, in September 2018, "decriminalized adultery in a landmark judgment aim[ing] at upholding the right to equality and freedom" (Mohanty \& Menon, 2018, para. 1). Dipak Misra, the Chief Justice of India stated that "[a]dultery cannot and should not be a crime" (para. 3). The opposing judgements of the judiciary in decriminalising marital rape against women and legalising adultery significantly depicts a major gap in the judicial process of India. The founder and director of Saitan theatre group, Rajneesh Gautam comments on the inefficiency of the judiciary to provide an impartial and effective protection grounds for women, "it is happening around us, and we are still showing ignorance" (Sharma, 2017, para.5). The ineffectiveness of the judiciary in case of marital rape is also criticised by Dwivedi (2014) who critiqued the gender biased laws in India which stated that, "sexual intercourse or sexual acts by a man with his own wife, the wife not being under fifteen years of age, is not rape" (p.6). However, it was reported that: "31\% of married women (nearly one in three) have been subjugated to physical, sexual and emotional violence at the hands of their spouse...83\% of married women between the ages of 15 and 49 who have ever suffered sexual abuse cite their current husband as the perpetrator, while 7\% refers to a former spouse" (Wangchuk, 2018, para. 5-7). Bhattacharya (2015) argues that these patterns of domestic violence (DV) are extended to SAAW (Sexual 
Assault against Women) in the public sphere. Her findings "delineate that the dynamics of DV against women behind closed doors is closely linked to the narrative of rising levels of SAAW in public spaces and is an enduring malaise that shackles women's mobility" (p.1350). The episodes above often certify that nothing substantial is practised in the bourgeoisie public discursive arena concerning sexual violence against women which ultimately leads patriarchal impunity to be intricately infused in the society.

While the state agencies do follow the rhetorical discourse in favour of the bourgeoisie public sphere, they also make sure that those who resist its functioning are forcibly made to submit discarding the possibility of any substantial betterment of excluded groups altogether. For resisting groups, "the legitimate achievement of political power [is sought] through recognition, when the interests and identities of a counterpublic are legitimated by wider publics or...the state" (Loehwing \& Motter, 2009, p.233). Table 3 is an attempt to paint some of the instances of sexual violence and injustices bestowed on the victims. It outlines the severe incompetence of the judiciary, in cases of sexual violence which, constantly refrains justice for the victims rejecting the discourse in the society. Therefore, it becomes perceptible that the role of police and judiciary in the cases of sexual violence against women happens to be very crucial in providing justice but their inability to act according to their duties further defers women's discourse to be exercised in reality.

\begin{tabular}{l|l|}
\multicolumn{2}{|c|}{ Table 3: Cases of Sexual Violence and Justice Denied to the Victims } \\
\hline $\begin{array}{l}\text { Incidents } \\
\text { Incompetent Judiciary }\end{array}$ \\
$\begin{array}{l}\text { A girl raped in Delhi when she was four years } \\
\text { old }\end{array}$ & $\begin{array}{l}\text { The case was dragged for nine years, and the } \\
\text { culprits were acquitted (Biswas, 2013) }\end{array}$ \\
$\begin{array}{l}\text { 31\% of married women subjugated to physical, } \\
\text { sexual and emotional violence at the hands of } \\
\text { their spouse }\end{array}$ & $\begin{array}{l}\text { Marital rape still not criminalised as an offence } \\
\text { (Wangchuk, 2018, para. 5-7) }\end{array}$ \\
$\begin{array}{l}\text { A Dalit woman in Delhi brutally molested and } \\
\text { paraded naked by upper caste }\end{array}$ & $\begin{array}{l}\text { Nine months later, the culprits still roam free } \\
\text { (Gunjan, 2018) }\end{array}$ \\
\hline
\end{tabular}

\section{Family and Sexual Violence against Women}

The unsympathetic and insensitive responses from the family overtly signify the dialectical rhetoric in the public sphere. It is disgusting to find that the rhetorical views concerning the safety of women against sexual violence are unfortunately not brought to practice even by the family of the victim. But the false system of beliefs like blaming the victim, the woman becoming impure after being violated or the victim being robbed of her honour, etc. are so powerfully diffused in the rhetorical space of bourgeoisie public sphere that the family, too, turns a slave to such myths thereby, accepting and practising them in their day to day lives (Bhattacharyya, 2015). Habermas also focuses on bourgeoisie public sphere "as a site of rhetorical legitimation" (as cited in Loehwing \& Motter, 2009, p.236) as it forms the basis of that "democratic culture" (as cited in Loehwing \&
Motter, 2009, p.236) which "influences institutional decision making, instead of extending the logic of institutions into the arena of citizen interaction" (as cited in Loehwing \& Motter, 2009, p.236). Thus, the families get swayed by the rhetorical discourse of the bourgeoisie public sphere making sure that matters of sexual violence do not get disclosed in public to save their name. Further, by pushing the grave violation into secrecy, the family of the victim itself takes part in the event of molestation increasing threatening aura of the perpetrators. Horrifying news came out from Delhi where the parents of a young rape victim were arrested on the charge of taking money from the culprits. The news reported that "some people known to the accused had approached her parents and offered ₹ [ 2 million] to get the girl change her statement in the court. Recently, they had given $₹$ [0.5 million] cash as advance 
payment" (Sharma, 2018, Table 4). The girl was thrashed and even pressurised to change her statement as she informed the police, "they kept trying to convince me and I stuck to my stand. The next morning they thrashed me and blackmailed me, saying that they were poor and needed that money" (Sharma, 2018). The heinous incidents like these expose the gruesome and frightful attitudes of the family of the perpetrator which makes it an active agent in encouraging violence against women. In another horrifying event, the parents of a teenager who was raped allegedly forced her to marry her rapist "to support the 10-month old baby born due to the rape" (Kokra, 2017). When the father was asked the reason behind making the pact with the rapist of his own daughter, he said, "samaaj se akele kab tak ladai karte... dardar bhatakne se to achha hai ki uske ghar chali gayi (How long can one fight against the society...it is better that she has gone to his house)" (Kokra, 2018). The incident explicitly exhibits the extent of pressure that the family members often exert on the victims. Often the families do not let the cases come into the notice of judiciary and consequently, social justice is hardly meted. The incidents represent the unfavourable and unsupportive attitudes of the families towards rape victims, but, it is inappropriate to generalise that every family bears indifferent and insensitive behaviour. However, it is also imperative to realise that people known to the victim commits the majority of the rapes. As per the data revealed by the National Crime Record Bureau (NCRB) in 2015, "in 95 per cent of all rape cases, the offender knew the victim" (Sharma, 2017). In the majority of the cases, the perpetrators are distant relatives, family members or friends, which makes it all the more difficult for the victim to report the crime. There remains a constant and indirect pressure on the victim from the family to silence the matter. According to the data analysis by Hindustan Times, "of 663 rape cases decided between January 2014 and March 2015 by Delhi courts, 357 resulted in acquittals because the victims turned hostile during the trial. At least 71 rape complainants deposed that they had filed false cases, under pressure from their family. The courts questioned neither the complainants nor...the families" (Mehta, 2016). While some families may be considerate and understanding, it cannot be ignored that the data recorded by various agencies validates that the majority of the rape cases are either not reported or withdrawn due to the compulsion of their families.

Another impediment that poses a threat to the victim's justice is the way its intimate partner deals with the plight of the victim. While the husband is ought to stand firmly with his wife to relieve her from the pain and misery, he, in turn, becomes the cause of her desolation and adversity in most of the cases, either by blaming the victim or deserting her, thus exhibiting the power of his status of being a husband. Fraser (1990) sheds light on why cases of marital rape are denied concern and deliberation, stating that "the rhetoric of domestic privacy seeks to exclude some issues and interests from public debate by personalising or familiarising them, it casts these as private-domestic or personalfamilial matters in contradistinction to public, political matters" (p.73) which "works to the advantage of dominant groups...and to the disadvantage of their subordinates" (p. 73). Siegel (1996), states that "the American legal system continued to treat wife beating differently from other cases of assault...Men who assaulted their wives were often granted formal and informal immunities from prosecution, in order to protect the privacy of the family and to promote domestic harmony" (p.1). Fraser and Siegel's comments concerning women are very much reflective of the similar predicament of women all over the world which is brutal, inhuman and suppressed.

It is also important to understand that in addition to the existence of a powerful and complex predominating patriarchal structure which functions to curb the freedom of women, social justice is also denied because of the victim itself. The 'self' here is extremely important because it is the victim who needs to have enough courage to fight in a male-dominated society and even if she tries, she is made weak 
by family, police, violators breaking her inner confidence The families, especially, that of the victims of sexual violence, unfortunately get caught in complying with the ideals of the bourgeoisie public sphere and become instrumental in suppressing the voice of the victim. Nonetheless, the families do participate in the rhetorical discourse which discusses and debates the predicament of women in cases of sexual violence with the aim of establishing a legitimate and reliable province against the bourgeoisie public discursive arena. As an example, it was Satyamev Jayate, the television

\begin{tabular}{ll}
\hline \multicolumn{2}{|c}{ Table 4: Reactions of Families Concerning Sexual Violence against Women } \\
\hline Incidents & The reaction of the Family \\
\hline A young girl is raped in Delhi & $\begin{array}{l}\text { Parents made a deal of ₹2 million with the } \\
\text { culprit to settle the case (Sharma, 2018) }\end{array}$ \\
$\begin{array}{l}\text { A teenage girl was raped, who gave birth to a } \\
\text { baby }\end{array}$ & $\begin{array}{l}\text { Family forced her to marry her rapist and sent } \\
\text { her to his home (Kokra, 2017) }\end{array}$ \\
\hline A woman in Gujarat raped for months & $\begin{array}{l}\text { Husband and the in-laws left her at her } \\
\text { parents' house refusing to accept her (“Indian } \\
\text { gang rape", 2015) }\end{array}$ \\
\hline
\end{tabular}

Table 4 above presents some shocking and horrible reactions of the family members towards sexual violence and its victims majorly neglecting its rhetorical discourse to be realised in practice. Therefore, the section concludes that until and unless families of the victim support them, they cannot fight for their rights alone resulting in a failure of the efficacious discourse created to fight against sexual violence against women.

\section{Society towards Sexual Violence against Women}

Majority of the reactions from the public towards the cases of sexual violence against women in India are reflective of the dominant prevailing ideology of the bourgeois public domain which has paved its way significantly from rhetoric into the reality. Such ideologies have often been publicised by various popular and respected figures of the country further validating the notion of the public sphere being highly masculinist. For instance, after 2012 Nirbhaya gang-rape case "the religious and political party leaders were busy in making their usual insensitive remarks e.g. a controversial show which addressed the grave crime of sexual violence on a national platform, brought families to tears. The show has had such an influential impact on the elders that it, "opened the eyes of millions, awakened the spirits of few and ignited a fire of ACTION in all" (Bhagel, 2014) and the audience was, "delighted to watch a meaty show on television after decades. They were indeed stunned, of knowing the ugly truth of Indian society (Bhagel, 2014). But despite such an encouraging milieu created by the show, the families decline to bring these ideas to practice. gang rape", 2015)

religious guru AasaramBapu's statement that the girl could have escaped rape had she addressed the rapists as "brother", International President of Vishva Hindu Parishad Mr Ashok Singhal held western culture responsible for sexual violence occurring in India, Madhya Pradesh Industry Minister Kailash Vijayvargiya had been advising women not to cross their lines, Rashtriya Swayam Sewak Sangh (RSS) chief Mohan Bhagwat shrugged this off by describing it as an urban phenomenon, Shafiqur Rehman, a member of a parliamentary committee on Home Affairs from Bahujan Samaj Party (BSP), held women's irresponsible dressing codes responsible for the assault, Andhra Pradesh Congress Chief, Botsa Satyanarayana argued as to why do women need to travel in the night?" (Dwivedi, 2014, p.1-2; Table 5). These observations bear resonance to the findings of Bhattacharyya (2015).

Society acts as an important factor in building a cohesive foundation for fabricating a mind-set conducive to women, but at the same time, it also plays a major role in deflecting it as well. Fraser (1990) suggests that "the force of public 
opinion is strengthened when a body representing it is empowered to translate such opinion into authoritative decisions" (p.75). However, since society falls through in replicating the ideas of procuring equity into practice, the initiative of undermining sexual violence against women gets interrupted. The Table 5 sums up the responses of the popular and renowned people of the country which are intricately constitutive of translating the beliefs

\begin{tabular}{|l|l|l|l|}
\hline \multicolumn{1}{|c}{ Table 5: Represents Renowned Personalities and their Remarks on Sexual Violence } \\
\hline Renowned Personalities & Remarks/ Statements \\
\hline Asaram Bapu on Nirbhaya's case & $\begin{array}{l}\text { The girls should have called the rapist her } \\
\text { brother to avoid sexual violence (Dwivedi, } \\
\text { 2014, p.1-2) }\end{array}$ \\
\hline Ashok Singhal & $\begin{array}{l}\text { Blamed western culture for the frequent } \\
\text { occurrence of sexual violence in India } \\
\text { (Dwivedi, 2014, p.1-2) }\end{array}$ \\
\hline Kailash Vijayvargiya & $\begin{array}{l}\text { Refrained women from crossing their lines } \\
\text { (Dwivedi, 2014, p.1-2) }\end{array}$ \\
\hline Shafiqur Rehman & $\begin{array}{l}\text { Blamed women's dressing codes for sexual } \\
\text { assaults taking place (Dwivedi, 2014, p.1-2) }\end{array}$ \\
\hline Mohan Bhagwat & $\begin{array}{l}\text { Called sexual violence against women an } \\
\text { urban phenomenon (Dwivedi, 2014, p.1-2) }\end{array}$
\end{tabular}

\section{Conclusion}

The paper analyses the disputable relationship shared between the rhetoric and the counterpublic in case of sexual violence against women, focusing on the way the effectuality of such discourses is hindered in the social practice due to the dialectic nature of the rhetoric. It explores that rhetoric as a discourse is indeed an important component both in bourgeoisie public sphere and the counter-public. However, its position in the bourgeoisie public sphere is contested, as it successfully brings to practice the patriarchally influenced ideology which becomes instrumental in excommunicating the women from the social praxis; and on the contrary, it fails to bring in effect the counterpublic formulated to provide an agency for the women to secure their identity in the bourgeoisie public sphere, thus, authenticating its dialectical nature.

The study examines different agencies like the public, media, police, judiciary, family, etc. which heavily subscribe to the norms and ideas of of the bourgeoisie public sphere from their rhetorical status. Due to a heavy condemnation of the society which on the one hand passes derogatory remarks on women who are sexually assaulted and on the other hand, declines to act against the perpetrators of the crime thus, relegating the course adopted to counter sexual violence against women as stagnant and ineffective in reality.

\section{Remarks/Statements}

brother to avoid sexual violence (Dwivedi, 2014, p.1-2) occurrence of sexual violence in India

Refrained women from crossing their lines assaults taking place (Dwivedi, 2014, p.1-2)

urban phenomenon (Dwivedi, 2014, p.1-2)

bourgeoisie public sphere, further posing hindrance in establishing a realistic ground for women to articulate their repression thus, validating the dialectical nature of the rhetorical space. The public being an eminent constituent of the public sphere plays a crucial role in translating the patriarchal ideologies from the rhetoric into actual practice, participating in the discursive realm of patriarchal bourgeoisie public sphere. The media, in a majority of the cases, presents an objectified version of women in the public sphere, often overshadowing the need for a legitimate antithetical space bringing forth the serious issue of sexual violence that are frequent in the society, thereby, failing to translate the rhetoric discourse into reality. Similarly, in addition to the dialectical rhetoric, the state agencies, family, society etc, further contribute in not only excluding the sensitive and responsible discourse of sexual violence against women but also participate in suspending the same discourse being conceived to end violence against women. 


\section{References}

Ali, A. (2001, 30 June). Evolution of public sphere in India. Economic and Political Weekly 36(26): 2419-2425

Bagaria, V. (2013, 3 July). Sexual harassment of Women at Workplace Act, 2013 - obligations for employers. Pleaders. Retrieved on 15 October 2018 from https://blog.ipleaders.in/sexual-harassment-ofwomen-at-workplace-act-2013-obligations-foremployers/

Batra, K. (2016, June). Creating a locational counterpublic: Manushi and the articulation of human rights and sexuality from Delhi, India. Journal of Women in Culture and Society 41(4): 845-867. Retrieved on 21 August 2018 from file://C:/Users/hp/Downloads/kanika\%20Batra .pdf

Beebeejaun, Y. (2016, December 23). Gender, urban space and the right to everyday life. Journal of Urban Affairs 39 (3): 323-334. Retrieved on 28 October 2018 from https://www.tandfonline.com/doi/full/10.1080 /07352166.2016.1255526?scroll=top\&needAcc ess=true

Bhalla, N. (2013, 13 January). Analysis: How India's police and judiciary fail rape victims [Blog Post]. Retrieved on 10 April 2018 from https://in.reuters.com/article/india-delhi-gangrape-women-safety-polic/analysis-how-indiaspolice-and-judiciary-fail-rape-victimsidINDEE90F0AY20130116

Bhagel, S. (2014, 31 October). Satmev Jayate: An Impact Analysis [Blog Post]. Retrieved on 11 April 2018 from https://qrius.com/satyamevjayate-an-impact-analysis/

Bhattacharyya, R. (2018, March). \# MeToo Movement: An Awareness Campaign. International Journal of Innovation, Creativity and Change 3(4): 1-12. Retrieved on 24 October 2018 from

http://www.ijicc.net/images/Mrach18_spec_ed ition/battacharyarra_March18.pdf

Bhattacharyya, Rituparna (2016). Street Violence against Indian Women in India: Mapping Prevention Strategies, Asian Social Work and
Policy Review, 10 (3), 311-325,

DOI:10.1111/aswp.12099

Bhattacharyya, Rituparna (2015). Understanding the spatialities of sexual assault against Indian women in India, Gender, Place and Culture, 22 (9), 1340-1356, http://dx.doi.org/10.1080/0966369X.2014.9696 84

Bhattacharyya, Rituparna (2013). Criminal Law (Amendment) Act, 2013: Will it ensure women's safety in public spaces? Journal Space and Culture, India, 1 (1), 13-27, DOI: http://dx.doi.org/10.20896/saci.v1i1.11

Biswas, T. (2013, 16 July). At four, she was raped cross-examined in court, denied justice. NDTV. Retrieved on 10 April 2018 from https://www.ndtv.com/india-news/at-four-shewas-raped-cross-examined-in-court-deniedjustice-528525

Bordia, R. (2017, 13 January).

Gulabi Gang, belan army and the fight for political power. NDTV. Retrieved on 15 August 2018 from https://www.ndtv.com/india-news/gulabigang-belan-gang-and-the-fight-for-politicalpower-1648566

Chandhoke, N. (2007, August). Civil society. Development in Practice 17(4-5): 607-614

Chandhoke, N. (2012. 9 June). Whatever has happened to civil society. Economic and Political Weekly XLVII (23): 39-45

Charles, G.U., \& Rohwer, L, F. (2015). Habermas, the public sphere, and the creation of a racial counterpublic. Michigan Journal of Race and Law 21(1): 1-21

"Crime in India 2016". (2017, 10 October).

National Crime Records Bureau. Retrieved on 15 October 2018 from

http://ncrb.gov.in/StatPublications/CII/CII2016/ pdfs/NEWPDFs/Crime\%20in\%20India\%20\%202016\%20Complete\%20PDF\%20291117.pdf

"Crime in India 2014". (2015, 8 July). National Crime Records Bureau. Retrieved on 15 October 2018 from http://www.ncrb.gov.in/StatPublications/CII/CII 2014/Compendium\%202014.pdf 
Das, M. (2018, 25 April). “Row over Saroj Khan's casting couch remark". The Times of India. Retrieved from https://timesofindia.indiatimes.com/city/mumb ai/row-over-saroj-khans-casting-couchremark/articleshow/63903866.cms

Desai, M. (1997, 5 May). Reflections from contemporary movements in India. Feminism and the New Democracy: 110-123

Dutta, D. \& Sircar, O. (2013). India's winter of discontent: some feminist dilemmas in the wake of a rape. Feminist Studies 39(1): 293-304

Dwivedi, A.V. (2014). Rape in the metropolis: The geography of crime in Delhi". Glocalism: Journal of Culture, Politics and Innovation 3: 1-9

Fraser, N. (1990). Rethinking the public sphere: A contribution to the critique of actually existing democracy. Social Text, No. 25/26: 56-80

"Facts and figures: Ending violence against women". ( 2017, August). UN Women.

Retrieved on 26 August 2018 from http://www.unwomen.org/en/what-wedo/ending-violence-against-women/facts-andfigures

Geetha, V. (2013). On Impunity. Economic and Political Weekly 48(02): 15-17

"Gender justice and its impediments". (2018, October 6). Economic and Political WeeklyLIII(40). Retrieved on 17 October 2018 from https://www.epw.in/system/files/pdf/2018_53 /40/ED_LIII_40_061018_Gender_Justice_and_It s_Impediments.pdf

Gunjan R. K. (2018, 10 March). No FIR no media coverage: Dalit woman facing sexual assault. News18. Retrieved on 12 April 2018 from https://www.news18.com/news/india/no-firno-media-coverage-dalit-women-facing-sexualassault-see-no-hope-of-getting-justice1684925.html

Habermas, J. (1989). The structural transformation of the public sphere: an inquiry into a category of bourgeois society. (T. Burger, Trans.). Cambridge: The MIT Press. (Original work published 1962)
Heaphy, L. (2017, 2May). The practice of Sati (widow burning). Kashgar. Retrieved on 15 October 2018 from

https://kashgar.com.au/blogs/history/thepractice-of-sati-widow-burning

Heanue S. (2018, 2 March). "Indian women sexually harassed at Delhi's Holi festival". $A B C$ News. Retrieved on 12 April 2018 from http://www.abc.net.au/news/2018-03-02/holifestival-abuse-in-india/9501132

"How to believe women". (2018, 6 October).

Economic and Political Weekly. Retrieved on 24 October 2018 from

https://www.epw.in/system/files/pdf/2018_53 /40/ED_LIII_40_061018_How_to_Believe_Wom en.pdf

"India: Rape victims face barriers to justice". (2017, 8 November). Human Rights Watch. Retrieved on 12 April 2018 from https://www.hrw.org/news/2017/11/08/indiarape-victims-face-barriers-justice

"Indian gang-rape victim faces 'purification ritual'". (2105, 14 June). BBC News. Retrieved on 12 April 2018 from https://www.bbc.com/news/world-asia-india32444349

"Kerala nun rape case: Bishop Mulakkal gets flower shower welcome in Jalandhar". (2018, 18 October). India Today. Retrieved on 28 October 2018 from https://www.indiatoday.in/india/story/support ers-shower-rose-petals-on-rape-accusedbishop-in-jalandhar-1370256-2018-10-18

Khan, S. (2017, December 19). Five years after Nirbhaya what has changed for women in public places. The Hindu. Retrieved on 28 October 2018 https://www.thehindu.com/society/five-yearsafter-nirbhaya/article21933310.ece

Kokra, S. (2017, 31 July). 14-year-old rape victim forced to marry alleged rapist to support the baby born out of rape. HuffPost. Retrieved on 2 May 2018 from https://www.huffingtonpost.in/2017/07/31/14year-old-rape-victim-forced-to-marry-allegedrapist-to-suppor_a_23057348/ 
Krishnamurthy, C. (2018, 9 October). Aloknath accused of rape by Vinita Nanda: 'I hadn't just been raped, I had been brutalised'. FilmiBeat. Retrieved on 25 October 2018 from https://www.filmibeat.com/television/2018/sa nskaari-babuji-alok-nath-accused-of-rapesexual-harrasement-by-tara-producer-vinitananda-278116.html

Loehwing, M., \& Motter, J. (2009). Publics, counterpublics and the promise of democracy. Philosophy and Rhetoric 42: 220-241

Mahajan, G. (1999, 4 December). Civil society, state and democracy. Economic and Political Weekly 34(49):3471-3472

Majumdar, N. (2017, September). Silencing the subaltern. Catalyst 1(1). Retrieved on 22 August 2018 from https://catalystjournal.com/vol1/no1/silencing-the-subaltern

Mehta, A. (2016, 28 April). Family, police pressure: Why most rape victims turn hostile during trial. Hindustan Times. Retrieved on 18 July 2018 from https://www.hindustantimes.com/india/whymost-rape-victims-turn-hostile-duringtrial/story-pjYLEJniCxceLIG6w6c8RK.html

Mohanty, S \& Menon, M. (2018, 27 September). India declares that adultery is no longer a crime, 3 weeks after legalising same-sex relations. Business Insider. Retrieved on 16 October 2018 from https://www.businessinsider.com/indiarules-adultery-is-no-longer-a-crime-20189? IR=T

"\#MeToo movement: sexual harassment allegations so far". (2018, 23 October ). The Times of India. Retrieved on 22 October 2018 from

https://timesofindia.indiatimes.com/india/met oo-movement-sexual-harassment-allegationsso-far/articleshow/66267346.cms

"Odisha: Alleged gang rape victim commits suicide over the delay in the investigation.(2018, 24 January). The Logical Indian. Retrieved on 10 May 2018 from https://thelogicalindian.com/news/gang-rapevictim-suicide-odisha/
Pleasance, C. (2015, 12 January). Indian teenager stoned to death by her father and brother because she loved somebody from the wrong village. Mail Online. Retrieved on 20 May 2018 from http://www.dailymail.co.uk/news/article2906949/Indian-teenager-stoned-death-fatherbrother-loved-somebody-wrong-village.html

"Policewoman, constable held for taking a bribe". (2017, 26 October). The Indian Express. Retrieved on 15 May 2018 from http://indianexpress.com/article/cities/pune/m aharashtra-policewoman-constable-held-fortaking-bribe-in-rape-case-4906748/

Presse, A. F. (2018, 9 July). The Nirbhaya rape case that rocked India. NDTV. Retrieved on 15 October 2018 from https://www.ndtv.com/india-news/thenirbhaya-rape-case-that-rocked-india-1880338

Reshma, M. \& Ramegowda, A. (2013, November). Dowry - The cancer of society. IOSR Journal Of Humanities And Social Science 17 (4): pp. 35-45. Retrieved on $15^{\text {th }}$ October 2018 from http://www.iosrjournals.org/iosrjhss/papers/Vol17-issue4/H01743545.pdf

"Sajid Khan accused of sexual harassment by three women. Read details here". (2018, 12 October). Hindustan Times. Retrieved on 25 October 2018 from https://www.hindustantimes.com/bollywood/s ajid-khan-accused-of-sexual-harassment-bythree-women-read-details-here/story06lhxgFFsNjYYpMAbWDINO.html

Sachdev, V. (2017, 15 December). How did the law change after Nirbhaya's case? The Quint. Retrieved on 15 October 2018 from https://www.thequint.com/videos/nirbhayacase-changes-to-criminal-law

Sethi, H \& Kothari, S. (1990). The non-party political process: Uncertain alternatives. New Delhi/Geneva: Lokayan/UNRISD.pp:308-29.

"Sexual harassment and Vishakha guidelines: All you need to know". (2013, 21 November). FirstPost. Retrieved on 15 October 2018 from https://www.firstpost.com/india/sexualharassment-and-vishakha-guidelines-all-youneed-to-know-1241649.html 
Sharma, K. (2017, 23 November). Why isn't marital rape criminal offence in India. The Times of India. Retrieved on 25 May 2018 from https://timesofindia.indiatimes.com/lifestyle/relationships/love-sex/Why-isntmarital-rape-a-criminal-offence-inIndia/articleshow/54223996.cms

Sharma, S. (2017, 9 May). NCRB data shows 95\% rape victims in India known to offenders; Madhya Pradesh tops the list. FirstPost. Retrieved on 10 August 2018 from https://www.firstpost.com/india/ncrb-datashows-95-rape-victims-in-india-known-tooffenders-3433136.html

Sharma, S. (2018, 12 April). Kathua rape case: Blatant support for barbaric act shows how bigotry, communal haze have numbed people. FirstPost. Retrieved on 28 October 2018 from https://www.firstpost.com/india/kathua-rapecase-blatant-support-for-barbaric-act-showshow-bigotry-communal-haze-have-numbedpeople-4429097.html

Sharma, V. (2018, 17 April). Teenage gang rape victim says parents took Rs 20 lakh hush money. International Business Times. Retrieved on 25 May 2018 from

https://www.ibtimes.co.in/teenage-gang-rapevictim-says-parents-took-rs-20-lakh-hushmoney-766897

Singh, S. (2018). Self-proclaimed God convicted, POCSO amended. Space and Culture, India 6(1): 7-15. Retrieved on 28 October 2018 from http://www.spaceandculture.in/index.php/spac eandculture/article/view/319/207

Siegel, R. B. (1996). The rule of love: Wife beating as prerogative and privacy. Yale Law School Legal ScholarshipRepository105: 1-93
"Speedy justice for rape victims? More than 133,000 cases pending". (2018, 19 April). Hindustan Times. Retrieved on 20 August 2018 from https://www.hindustantimes.com/indianews/speedy-justice-for-rape-victims-morethan-133-000-cases-pending/storyZkQEq5SBbjVqm0aFIR6all.html

Srinivas, M.N. (1985). Caste in modern India and other essays. Bombay: Media Promoters and Publishers

Tiwari, R. (2006, July). Habermas's views on the significance of the public sphere in democracy. The Indian Journal of Political Science LXVII(3): 640-650

"Remember Kathua". (April 2018). Economic and Political Weekly53 (15): pp. 1-7

Wangchuk, R.N. (2018, March 16). The survey takes the veil off marital rape in India: it's time we had a serious discussion. The Better India. Retrieved on 16 October 2018 from https://www.thebetterindia.com/134673/surve y-nfhs-marital-rape-india/

"Woman raped by the side of the road in India as people film her instead of helping her". (2017, October 26). The Express Tribune. Retrieved on 27 May 2018 from https://tribune.com.pk/story/1541528/3woman-raped-side-road-india-people-filminstead-helping/

Zargar, A. R. (2018, 13 April). Young girl's brutal rape and murder highlights a religious divide. CBS News. Retrieved on 27 May 2018 from https://www.cbsnews.com/news/india-rapemurder-muslim-girl-asifa-bano-hindu-radialsrally-for-suspects/ 